\title{
BMJ Open Association between serum magnesium concentration and metabolic syndrome, diabetes, hypertension and hyperuricaemia in knee osteoarthritis: a cross-sectional study in Hunan Province, China
}

Yilun Wang, ${ }^{1}$ Jie Wei, ${ }^{2}$ Chao Zeng, ${ }^{1}$ Tuo Yang, ${ }^{1}$ Hui Li, ${ }^{1}$ Yang Cui, ${ }^{3}$ Dongxing Xie, ${ }^{1}$ Bei Xu, ${ }^{1}$ Zhichen Liu, ${ }^{1}$ Jiatian Li, ${ }^{1}$ Shide Jiang, ${ }^{1}$ Guanghua Lei ${ }^{1}$

To cite: Wang Y, Wei J, Zeng $\mathrm{C}$, et al. Association between serum magnesium concentration and metabolic syndrome, diabetes, hypertension and hyperuricaemia in knee osteoarthritis: a crosssectional study in Hunan Province, China. BMJ Open 2018;8:e019159. doi:10.1136/ bmjopen-2017-019159

- Prepublication history for this paper is available online. To view these files, please visit the journal online (http://dx.doi. org/10.1136/bmjopen-2017019159).

Received 14 August 2017 Revised 31 July 2018 Accepted 7 August 2018
Check for updates

(C) Author(s) (or their employer(s)) 2018. Re-use permitted under CC BY-NC. No commercial re-use. See rights and permissions. Published by BMJ.

For numbered affiliations see end of article.

Correspondence to

Dr Guanghua Lei;

lei_guanghua@csu.edu.cn

\section{ABSTRACT}

Objectives To examine the associations between serum magnesium $(\mathrm{Mg})$ concentration with the prevalence of metabolic syndrome (MetS), diabetes mellitus (DM), hypertension $(\mathrm{HP})$ and hyperuricaemia $(\mathrm{HU})$ in patients with radiographic knee osteoarthritis $(\mathrm{OA})$.

Methods The present study was conducted at the Health Management Center of Xiangya Hospital. Radiographic OA was evaluated for patients aged over 40 years with basic characteristics and blood biochemical assessment. Serum Mg concentration was measured using the chemiluminescence method. MetS, DM, HP and HU were diagnosed based on standard protocols. The associations between serum Mg concentration with MetS, DM, HP and HU were evaluated by conducting multivariable adjusted logistic regression.

Results A total of 962 patients with radiographic knee $0 A$ were included. Compared with the lowest quintile, the multivariable adjusted ORs and related $95 \%$ Cls of DM were 0.40 (95\% Cl 0.23 to $0.70, \mathrm{p}=0.001), 0.33(95 \%$ Cl 0.18 to $0.60, p<0.001), 0.27$ (95\% Cl 0.14 to 0.52 , $\mathrm{p}<0.001)$ and $0.22(95 \% \mathrm{Cl} 0.11$ to $0.44, \mathrm{p}<0.001)$ in the second, third, fourth and highest quintiles of serum $\mathrm{Mg}$, respectively ( $\mathrm{p}$ for trend $<0.001$ ); the multivariable adjusted ORs of HU were 0.33 (95\% $\mathrm{Cl} 0.19$ to 0.59 , $\mathrm{p}<0.001), 0.52$ (95\% $\mathrm{Cl} 0.30$ to $0.91, \mathrm{p}=0.022)$ and 0.39 $(95 \% \mathrm{Cl} 0.22$ to $0.70, \mathrm{p}=0.001)$ in the third, fourth and highest quintiles of serum $\mathrm{Mg}$, respectively ( $\mathrm{p}$ for trend $<0.001$ ); and the multivariable adjusted ORs of MetS were $0.59(95 \% \mathrm{Cl} 0.36$ to $0.94, \mathrm{p}=0.027)$ in the second and $0.56(95 \% \mathrm{Cl} 0.34$ to $0.93, \mathrm{p}=0.024)$ in the highest quintiles of serum $\mathrm{Mg}$. However, the inverse association between serum $\mathrm{Mg}$ and the prevalence of MetS was non-linear ( $p$ for trend=0.067). There was no significant association between serum $\mathrm{Mg}$ and HP in patients with $0 A$.

Conclusions The serum Mg concentration was inversely associated with the prevalence of MetS, DM and $\mathrm{HU}$ in patients with radiographic knee $0 \mathrm{~A}$.

Level of evidence Level III, cross-sectional study.

\section{Strengths and limitations of this study}

This is the first study examining the associations between serum magnesium $(\mathrm{Mg})$ and the prevalence of metabolic syndrome, diabetes mellitus, hypertension and hyperuricaemia in patients with radiographic knee osteoarthritis

- The multivariable logistical regression models in this study were adjusted for a considerable number of potential confounding factors, which greatly improved the reliability of the results.

- The kidney is the key organ in maintaining Mg homoeostasis. This study conducted a sensitivity analysis by adding estimated glomerular filtration rate into the multivariable logistic regression models, and the reverse associations remained significant.

- This study adopted cross-sectional design, which precluded causal correlations.

- Serum Mg concentration was adopted as the indicator of body Mg content in this study, which may not be the best indicator of body status.

\section{INTRODUCTION}

The association between osteoarthritis (OA) and metabolic diseases, especially metabolic syndrome $(\mathrm{MetS})^{12}$ and diabetes mellitus (DM) ${ }^{3-5}$ has drawn increasing attention in the past few years. OA includes three specific phenotypes: metabolic OA, age-related $\mathrm{OA}$ and injury-related $\mathrm{OA}^{6}{ }^{6}$ A large number of studies have indicated that the prevalence of MetS, ${ }^{7-9} \mathrm{DM}^{10-18}$ and hypertension (HP) ${ }^{79-131920}$ is either higher in patients with OA or associated with OA. In addition, some other studies reported that MetS, ${ }^{21}{ }^{22} \mathrm{DM}^{23} 24$ and $\mathrm{HP}^{21} 22$ are risk factors of OA progression. Thus, it appears necessary to pay more attention and adopt appropriate measures 
to reduce the high prevalence of metabolic diseases in patients with $\mathrm{OA}$, which also seems to be beneficial in delaying OA progression.

Serum magnesium $(\mathrm{Mg})$, one of the most important micronutrients for human health, has been reported to be negatively associated with MetS, ${ }^{25-29} \mathrm{DM}^{30-38}$ and $\mathrm{HP}^{30}{ }^{39-41}$ by lots of studies. Meanwhile, our previous study showed an inverse association between serum $\mathrm{Mg}$ and hyperuricaemia (HU) ${ }^{42}$ However, to the best knowledge of the authors, there is not yet a study examining the association between the serum $\mathrm{Mg}$ concentration and the aforementioned metabolic diseases (MetS, DM, HP and $\mathrm{HU}$ ) in patients with OA. On the other hand, we have previously shown that the serum $\mathrm{Mg}$ concentration may be inversely associated with radiographic knee OA. ${ }^{43}$ Therefore, we speculate that the prevalence of MetS, DM, HP and HU in patients with OA may be reduced by elevating the level of serum $\mathrm{Mg}$, which can in turn delay OA progression. Thus, the objective of the present study was to examine the associations between the serum $\mathrm{Mg}$ concentration with the prevalence of MetS, DM, HP and $\mathrm{HU}$ in patients with radiographic knee OA. It was hypothesised that serum $\mathrm{Mg}$ concentration was inversely associated with these diseases.

\section{METHODS}

\section{Study population}

The present study was conducted at the Health Management Center of Xiangya Hospital between October 2013 and November 2014. The study design has been published previously. ${ }^{42-46}$ Registered nurses were engaged to interview all participants during the examination using a standard questionnaire, with the purpose to collect information on demographic characteristics and health-related habits. Participants were selected based on the following inclusion criteria: (1) 40 years old or above; (2) undergoing weight-bearing bilateral anteroposterior radiography of the knee, and diagnosed with knee OA according to the Kellgren-Lawrence (K-L) radiographic atlas (knee joint was graded K-L 2 or above); (3) availability of all basic characteristics, including age, gender, Body Mass Index (BMI) and blood pressure; (4) availability of biochemical test results, including serum $\mathrm{Mg}$ concentration; (5) availability of information related to the living habits, including education background, activity level, smoking, drinking and medication status. Initially, the present cross-sectional study retrieved 1820 patients with radiographic knee OA aged over 40 years who exhibited sound basic characteristics and required blood biochemical assessment (including serum $\mathrm{Mg}$ concentration). Among them, 962 patients offered demographic characteristics and health-related habits and were finally included in this study.

\section{Blood biochemistry}

All blood samples were drawn after a 12-hour overnight fast and were kept at $4^{\circ} \mathrm{C}$ until analysis. Blood tests were undertaken using the Beckman Coulter AU 5800 (Beckman Coulter, Brea, California, USA). The interassay and intra-assay coefficients of variation were tested at both low concentrations $(2.5 \mathrm{mmol} / \mathrm{L}$ for glucose, 118 $\mu \mathrm{mol} / \mathrm{L}$ for uric acid and $0.60 \mathrm{mmol} / \mathrm{L}$ for serum $\mathrm{Mg}$ ) and high concentrations $(6.7 \mathrm{mmol} / \mathrm{L}$ for glucose, 472 $\mu \mathrm{mol} / \mathrm{L}$ for uric acid and $1.00 \mathrm{mmol} / \mathrm{L}$ for serum $\mathrm{Mg}$ ) of standard human samples. The intra-assay coefficients of variation were $0.98 \%(2.5 \mathrm{mmol} / \mathrm{L})$ and $1.72 \%(6.7$ $\mathrm{mmol} / \mathrm{L})$ for glucose, $1.39 \%(118 \mu \mathrm{mol} / \mathrm{L})$ and $0.41 \%$ $(472 \mu \mathrm{mol} / \mathrm{L})$ for uric acid, and $1.86 \%(0.60 \mathrm{mmol} / \mathrm{L})$ and $1.65 \%(1.00 \mathrm{mmol} / \mathrm{L})$ for serum $\mathrm{Mg}$, respectively. The inter-assay coefficients of variation were $2.45 \%(2.5$ $\mathrm{mmol} / \mathrm{L})$ and $1.46 \%(6.7 \mathrm{mmol} / \mathrm{L})$ for glucose, $1.40 \%$ $(118 \mu \mathrm{mol} / \mathrm{L})$ and $1.23 \%(472 \mu \mathrm{mol} / \mathrm{L})$ for uric acid, and $1.87 \%(0.60 \mathrm{mmol} / \mathrm{L})$ and $1.70 \%(1.00 \mathrm{mmol} / \mathrm{L})$ for serum $\mathrm{Mg}$, respectively.

\section{Assessment of other exposures}

Blood pressure was measured by an electronic sphygmomanometer. The weight and height of each subject were measured respectively to calculate the BMI. Information on the average frequency of physical activity (never, one to two times per week, three to four times per week, five times and above per week) and average duration of physical activity (less than half an hour, half an hour to 1 hour, 1 to 2 hours, more than 2 hours) were collected through survey questionnaire. The smoking, alcohol drinking and medication status were collected during the face-to-face interview.

\section{Assessment of MetS, DM, HP and HU}

MetS was diagnosed based on the Chinese Diabetes Society criteria, ${ }^{47-49}$ which requires meeting at least three of the following four items: (1) BMI $\geq 25 \mathrm{~kg} / \mathrm{m}^{2}$; (2) fasting plasma glucose $\geq 6.1 \mathrm{mmol} / \mathrm{L}$ or diagnosed $\mathrm{DM}$; (3) systolic blood pressure (BP) $\geq 140 \mathrm{~mm} \mathrm{Hg}$ or diastolic $\mathrm{BP} \geq 90 \mathrm{~mm} \mathrm{Hg}$, or treatment of previously diagnosed $\mathrm{HP}$; (4) triglycerides $\geq 1.7 \mathrm{mmol} / \mathrm{L}$ and/or high-density lipoprotein (HDL) cholesterol $<0.9 \mathrm{mmol} / \mathrm{L}$ in men or $<1.0 \mathrm{mmol} / \mathrm{L}$ in women, or treatment for this lipid abnormality. Subjects with fasting glucose $\geq 7.0 \mathrm{mmol} / \mathrm{L}$ or currently undergoing drug treatment for blood glucose control were regarded as patients with DM, and subjects with systolic BP $\geq 140 \mathrm{~mm} \mathrm{Hg}$ or diastolic BP $\geq 90 \mathrm{~mm} \mathrm{Hg}$ or currently undertaking antihypertensive medication were regarded as patients with HP. HU was defined as uric acid $\geq 416 \mu \mathrm{mol} / \mathrm{L}$ for men and $\geq 360 \mu \mathrm{mol} / \mathrm{L}$ for women or currently undergoing drug treatment for uric acid control.

\section{Statistical analysis}

The continuous data were expressed as mean with SD, and the category data were expressed in percentage. Differences in continuous data were evaluated by one-way classification analysis of variance (normally distributed data) or Kruskal-Wallis $\mathrm{H}$ test (non-normally distributed data), while differences in category data were assessed by 
the $\chi^{2}$ test. The serum Mg was classified into five categories based on the quintile distribution: $\leq 0.85,0.86-0.89$, $0.90-0.92,0.93-0.96$ and $\geq 0.97 \mathrm{mmol} / \mathrm{L}$. The prevalence of MetS, DM, HP and HU in each quintile of serum $\mathrm{Mg}$ in patients with OA was assessed by scatter plots.

Logistic regression was conducted to calculate the ORs with $95 \%$ CIs for the associations between serum $\mathrm{Mg}$ and MetS, DM, HP and HU. Specifically, model 1 was adjusted by covariates of age (continuous data) and gender (male, female). Then, model 2 was adjusted by additional covariates of BMI (continuous data), educational level (high school or above, lower than high school), smoking status (yes, no), activity level (continuous data), alcohol drinking status (yes, no), HP (yes, no), DM (yes, no) and dyslipidemia (yes, no) on the basis of model 1. Dyslipidemia was defined as triglycerides $\geq 1.7 \mathrm{mmol} / \mathrm{L}$ and/or HDL cholesterol $<0.9 \mathrm{mmol} / \mathrm{L}$ in men or $<1.0 \mathrm{mmol} / \mathrm{L}$ in women, or treatment for this lipid abnormality. Notably, the selection of covariates in model 2 varied slightly for examining different associations (between serum $\mathrm{Mg}$ and MetS, DM, HP or HU). For example, BMI, HP and dyslipidemia were adjusted for the association between serum $\mathrm{Mg}$ and DM, but not for the association between serum $\mathrm{Mg}$ and MetS, simply because MetS was diagnosed based on BMI, HP and dyslipidemia status. Model 3 was established based on model 2, with adjustment of an additional covariate, estimated glomerular filtration rate (eGFR). eGFR (continuous data) was calculated from the Chronic Kidney Disease Epidemiology Collaboration equation. ${ }^{50}$ All covariates in the present study were chosen referring to some of the previous similar studies. ${ }^{27335152}$ Tests for linear trends were conducted based on logistic regression using a median variable of $\mathrm{Mg}$ concentration in each category.

Scatter plots were plotted using R V.3.4.4. ${ }^{53}$ Other data analyses were performed using SPSS V.17.0; $p$ value $\leq 0.05$ was considered to be statistically significant. All tests were two tailed.

\section{Patient and public involvement}

No patients were involved in setting the research question or the outcome measures, nor were they involved in the design or implementation of the study. There were no plans to disseminate the results of the research to study participants.

\section{RESULTS}

A total of 962 subjects (377 women, accounting for 39.2\%) were included in the present cross-sectional study. The characteristics of the study population according to quintiles of serum $\mathrm{Mg}$ are presented in table 1. The mean age of the subjects was $54.9 \pm 7.6$ years. The overall prevalence of MetS, DM, HP and HU in patients with OA were $21.4 \%, 12.0 \%$, $38.5 \%$ and $18.3 \%$, respectively. Significant differences were observed across the quintiles of serum $\mathrm{Mg}$ for fasting glucose, as well as the prevalence of DM and HU.

The prevalence of MetS in each quintile of serum $\mathrm{Mg}$ in patients with OA is shown in figure 1A. The outcomes of multivariable adjusted associations between MetS and serum $\mathrm{Mg}$ concentration are shown in table 2. Compared with the lowest quintile, the age-gender adjusted ORs (model 1) suggested significant decreased prevalence of MetS in the second (OR $0.61,95 \%$ CI 0.38 to 0.97 , $\mathrm{p}=0.038$ ) and the highest (OR $0.59,95 \%$ CI 0.36 to 0.96 , $\mathrm{p}=0.035$ ) quintiles of serum $\mathrm{Mg}$; the multivariable adjusted ORs (model 2) also suggested significant decreased prevalence of MetS in the second (OR 0.60, 95\% CI 0.37 to $0.96, \mathrm{p}=0.035$ ) and the highest (OR $0.61,95 \%$ CI 0.37 to $0.99, \mathrm{p}=0.047$ ) quintiles. The sensitivity analysis, by adding eGFR into model 2, also reached similar results-significant lower prevalence of MetS in the second (OR 0.59, $95 \%$ CI 0.36 to $0.94, \mathrm{p}=0.027$ ) and the highest quintiles (OR $0.56,95 \%$ CI 0.34 to $0.93, \mathrm{p}=0.024$ ) compared with the reference quintile of serum $\mathrm{Mg}$. No clear trend was evident in the third and fourth quintiles of serum $\mathrm{Mg}$. The $\mathrm{p}$ values for trend were 0.090 (model 1), 0.120 (model 2) and 0.067 (model 3), respectively.

Figure 1B shows the prevalence of DM in each category of serum $\mathrm{Mg}$ in patients with OA. Table 3 illustrates the multivariable adjusted relations between serum $\mathrm{Mg}$ and DM in patients with OA. Both the age-gender adjusted OR values (model 1 ) and the multivariable adjusted OR values (model 2) suggested a strong inverse association between serum $\mathrm{Mg}$ and DM. The age-gender adjusted ORs for the prevalence of DM were 0.38 (95\% CI 0.22 to $0.66, \mathrm{p}=0.001), 0.34$ (95\% CI 0.19 to $0.61, \mathrm{p}<0.001), 0.29$ (95\% CI 0.15 to $0.55, \mathrm{p}<0.001)$ and 0.20 (95\% CI 0.10 to $0.40, \mathrm{p}<0.001)$ in the second, third, fourth and fifth quintiles of serum $\mathrm{Mg}$, respectively, and the $\mathrm{p}$ value for trend was $<0.001$. The multivariable adjusted ORs for the prevalence of DM were 0.40 (95\% CI 0.23 to $0.70, \mathrm{p}=0.001$ ), 0.32 (95\% CI 0.18 to $0.59, \mathrm{p}<0.001$ ), 0.26 (95\% CI 0.13 to $0.50, \mathrm{p}<0.001)$ and $0.21(95 \%$ CI 0.11 to $0.42, \mathrm{p}<0.001)$ in the second, third, fourth and fifth quintiles of serum $\mathrm{Mg}$, respectively, and the $p$ value for trend was $<0.001$. The sensitivity analysis, by adding eGFR into model 2 , showed similar results-significant lower prevalence of DM in the second (OR $0.40,95 \% \mathrm{CI} 0.23$ to $0.70, \mathrm{p}=0.001$ ), third (OR $0.33,95 \%$ CI 0.18 to $0.60, \mathrm{p}<0.001$ ), fourth (OR 0.27 , $95 \% \mathrm{CI} 0.14$ to $0.52, \mathrm{p}<0.001)$ and highest quintiles (OR $0.22,95 \%$ CI 0.11 to $0.44, \mathrm{p}<0.001$ ) compared with the reference quintile of serum $\mathrm{Mg}$, and the $\mathrm{p}$ value for trend was $<0.001$.

The prevalence of $\mathrm{HP}$ in each quintile of serum $\mathrm{Mg}$ in patients with $\mathrm{OA}$ is depicted in figure 1C. The multivariable adjusted relations between serum $\mathrm{Mg}$ and $\mathrm{HP}$ in patients with $\mathrm{OA}$ are illustrated in table 4. According to both the age-gender adjusted ORs (model 1) and the multivariable adjusted ORs (model 2), there was no significant association between serum $\mathrm{Mg}$ and $\mathrm{HP}$, and the $p$ values for trend were 0.929 and 0.377 , respectively. The sensitivity analysis, by adding eGFR into model 2 , reached the same results.

The prevalence of $\mathrm{HU}$ in each category of serum $\mathrm{Mg}$ in patients with OA is shown in figure 1D. The multivariable adjusted relations between serum $\mathrm{Mg}$ and 
Table 1 Basic characteristics of included subjects according to quintiles of serum $\mathrm{Mg}(\mathrm{n}=962)$

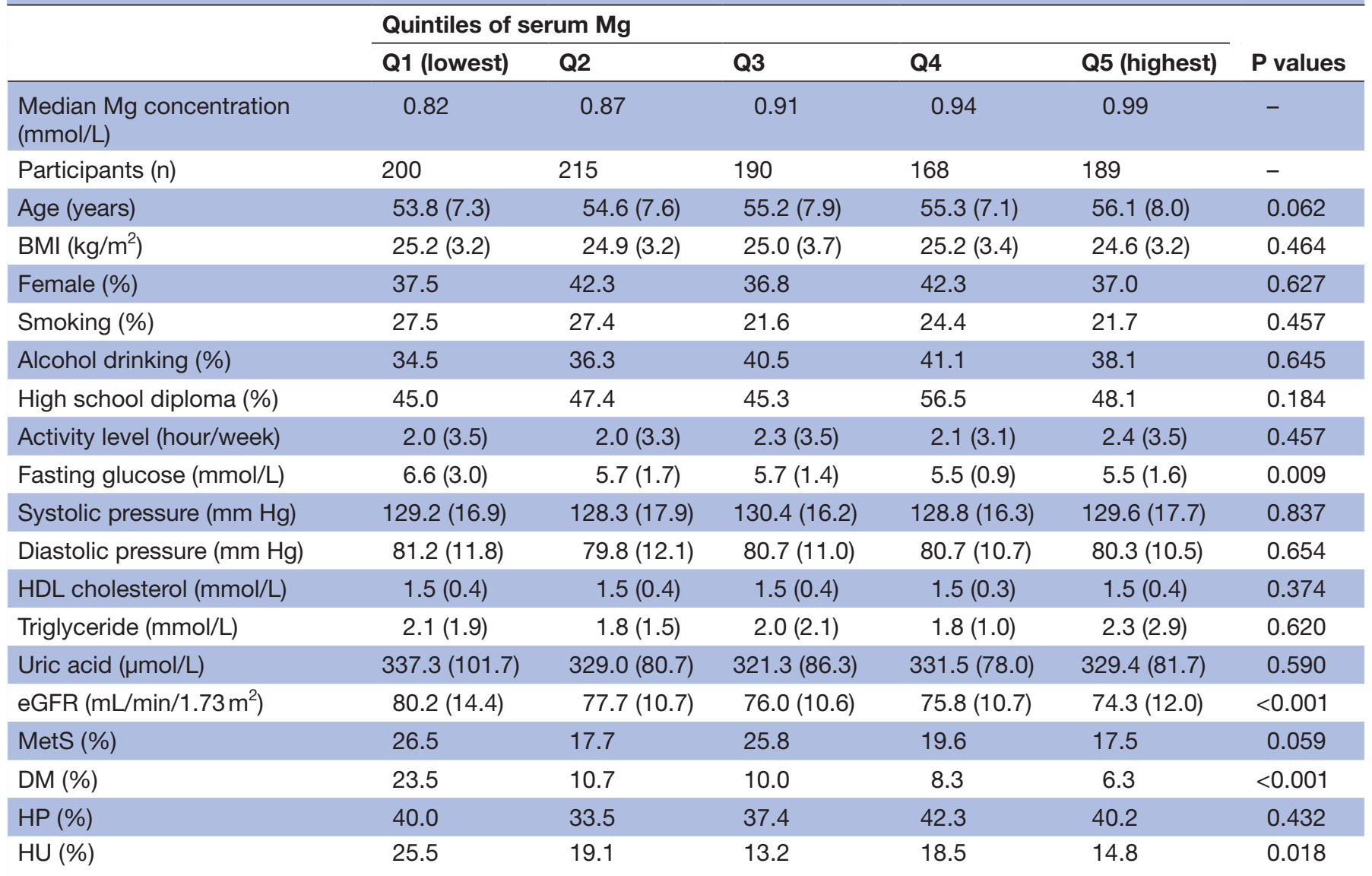

Data are mean (SD), unless otherwise indicated. $\mathrm{P}$ values are for test of difference across all quintiles of serum $\mathrm{Mg}$.

BMI, Body Mass Index; DM, diabetes mellitus; eGFR, estimated glomerular filtration rate; HDL, high-density lipoprotein; HP, hypertension; $\mathrm{HU}$, hyperuricaemia; MetS, metabolic syndrome; Mg, magnesium.

HU in patients with $\mathrm{OA}$ are illustrated in table 5. Both the age-gender adjusted OR values (model 1$)$ and the multivariable adjusted OR values (model 2) suggested significant decreased prevalence of $\mathrm{HU}$ in the third quintile (age-gender adjusted OR $0.44,95 \%$ CI 0.26 to $0.75, \mathrm{p}=0.002$; multivariable adjusted OR $0.38,95 \% \mathrm{CI}$ 0.22 to $0.67, \mathrm{p}=0.001$ ) and fifth quintile (age-gender adjusted OR $0.51,95 \%$ CI 0.30 to $0.85, \mathrm{p}=0.010$; multivariable adjusted OR $0.50,95 \%$ CI 0.29 to $0.87, p=0.013$ ) compared with the lowest quintile of serum $\mathrm{Mg}$, and the $\mathrm{p}$ values for trend were 0.008 and 0.006 , respectively. The sensitivity analysis, by adding eGFR into model 2 , showed similar outcomes-significant lower prevalence of $\mathrm{HU}$ in the third (OR $0.33,95 \%$ CI 0.19 to $0.59, \mathrm{p}<0.001$ ), fourth (OR $0.52,95 \%$ CI 0.30 to $0.91, \mathrm{p}=0.022$ ) and highest quintiles (OR $0.39,95 \%$ CI 0.22 to $0.70, \mathrm{p}=0.001$ ) compared with the reference quintile of serum $\mathrm{Mg}$, and the $\mathrm{p}$ value for trend was $<0.001$.

\section{DISCUSSION}

The results of this study suggested that the serum $\mathrm{Mg}$ concentration was negatively associated with the prevalence of MetS, DM and HU in subjects with radiographic knee OA. To control potential confounders, several covariates including characteristics, living habits and underlying diseases were selected, and even the eGFR was added into the multivariable logistic regression models to eliminate the influence of renal function on $\mathrm{Mg}$ excretion. The reverse associations mentioned above remained significant after adjustments of these confounders. However, the association between serum $\mathrm{Mg}$ and the prevalence of MetS was non-linear, with no clear trend in the third and fourth quintiles of serum $\mathrm{Mg}$. Moreover, the negative association between serum $\mathrm{Mg}$ and the prevalence of HP was not observed in patients with radiographic knee OA.

$\mathrm{Mg}$, the fourth most abundant cation in the human body and the second most profuse intracellular cation, is a metallic cofactor for over 300 enzymatic reactions. It appears to play an important role in glucose metabolism and insulin homoeostasis, which are both highly correlated with metabolic diseases, especially MetS and DM. The mechanisms involved in $\mathrm{Mg}$ deficiency in patients with MetS, DM and HU are probably multifactorial. The most important factor may be insulin resistance, as $\mathrm{Mg}$ is essential for insulin action and is a critical cofactor for several enzymes in carbohydrate metabolism, which is important for the phosphorylation reactions of 
A

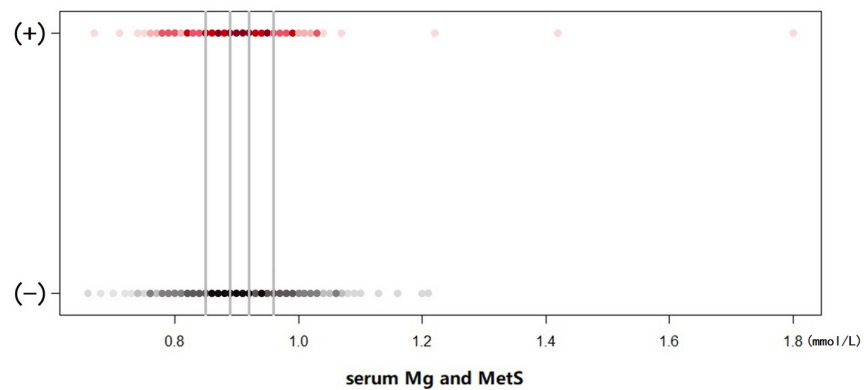

C

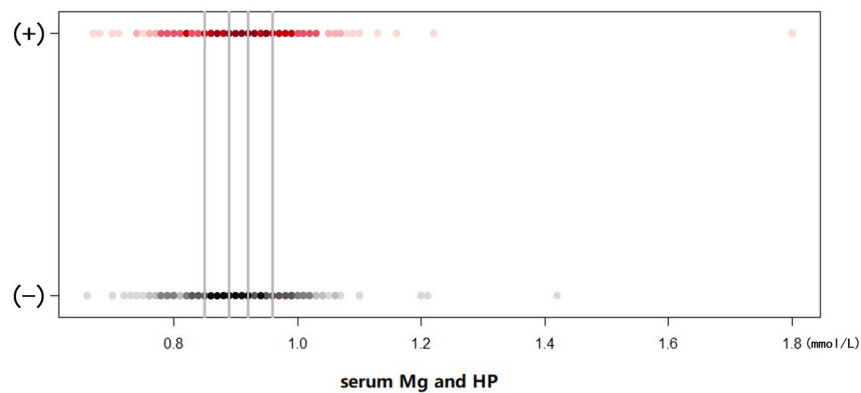

B

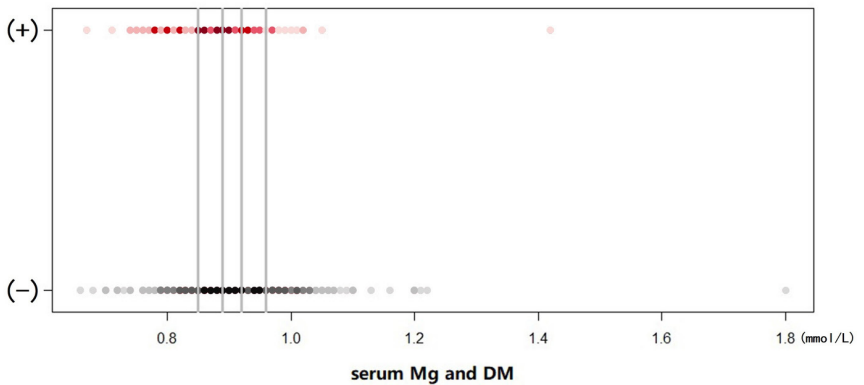

D

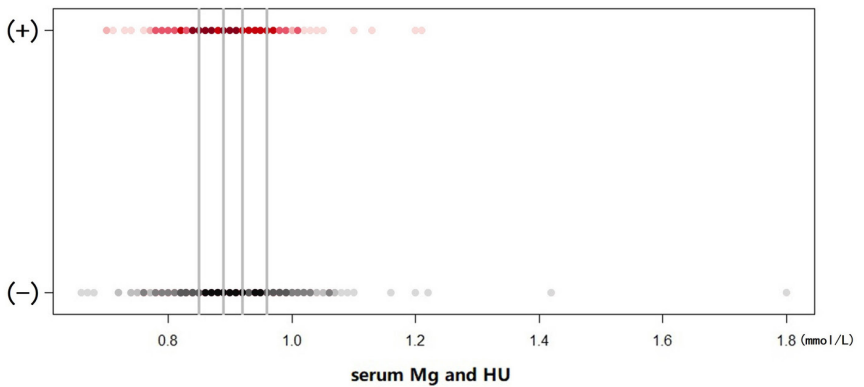

Figure 1 Prevalence of metabolic syndrome (MetS) (A), diabetes mellitus (DM) (B), hypertension (HP) (C) and hyperuricaemia (HU) (D) in each quintile of serum $\mathrm{Mg}$ in patients with radiographic knee $\mathrm{OA}$. The figures above present the prevalence of MetS (A), DM (B), HP (C) and HU (D) among the 962 patients with OA under different quintiles of serum Mg levels. The horizontal axis denotes the serum Mg level, and the vertical axis indicates whether a subject is diagnosed with the specific disease: (+), disease; (-), no disease. The solid grey lines represent the boundaries in between the five quintiles of serum Mg levels. The red and black spots represent the prevalence of diseases and no diseases at each serum $\mathrm{Mg}$ level, respectively. The darker the colour of a spot, the more patients with OA there are at the corresponding concentration.

tyrosine kinase in the insulin receptor. ${ }^{31}{ }^{54-58}$ Of course, it is necessary to highlight the fact that insulin can also induce $\mathrm{Mg}$ excretion $^{59}$ and produce a significant decline of plasma Mg through ion exchange. ${ }^{60}$ Thus, there seems to be a vicious circle between $\mathrm{Mg}$ deficiency and insulin resistance.

Other potential mechanisms include glucose transportation, ${ }^{57}$ oxidative stress ${ }^{57}$ and inflammatory cytokines, ${ }^{61-63}$

Table 2 Multivariable adjusted relations of serum Mg and MetS in patients with OA $(n=962)$

\begin{tabular}{|c|c|c|c|c|c|c|}
\hline & \multicolumn{5}{|c|}{ Quintiles of serum $\mathbf{M g}$} & \multirow{2}{*}{$\begin{array}{l}\text { P for } \\
\text { trend }\end{array}$} \\
\hline & Q1 (lowest) & Q2 & Q3 & Q4 & Q5 (highest) & \\
\hline $\begin{array}{l}\text { Median } \mathrm{Mg} \\
\text { concentration (mmol/L) }\end{array}$ & 0.82 & 0.87 & 0.91 & 0.94 & 0.99 & - \\
\hline Participants (n) & 200 & 215 & 190 & 168 & 189 & - \\
\hline MetS (\%) & 26.5 & 17.7 & 25.8 & 19.6 & 17.5 & - \\
\hline Model 2* & 1.00 (reference) & 0.60 (0.37 to 0.96$)$ & 1.00 (0.63 to 1.57$)$ & $0.70(0.42$ to 1.15$)$ & 0.61 (0.37 to 0.99$)$ & 0.120 \\
\hline$P$ values & - & 0.035 & 0.985 & 0.160 & 0.047 & - \\
\hline Model 3* & 1.00 (reference) & 0.59 (0.36 to 0.94$)$ & 0.95 (0.60 to 1.51$)$ & 0.67 (0.40 to 1.10$)$ & 0.56 (0.34 to 0.93$)$ & 0.067 \\
\hline$P$ values & - & 0.027 & 0.830 & 0.114 & 0.024 & - \\
\hline
\end{tabular}

Data are adjusted OR $(95 \% \mathrm{Cl})$, unless otherwise indicated.

*Model 1 was adjusted for age (continuous data) and gender (male, female); model 2 was adjusted for age (continuous data), gender (male, female), educational level (high school or above, lower than high school), smoking status (yes, no), activity level (continuous data) and alcohol drinking status (yes, no); model 3 was adjusted based on model 2, with additional factor of estimated glomerular filtration rate (continuous data).

MetS, metabolic syndrome; Mg, magnesium; n, number; OA, osteoarthritis. 
Table 3 Multivariable adjusted relations of serum $\mathrm{Mg}$ and DM in patients with OA $(n=962)$

\begin{tabular}{|c|c|c|c|c|c|c|}
\hline & \multicolumn{5}{|c|}{ Quintiles of serum $\mathbf{M g}$} & \multirow{2}{*}{$\begin{array}{l}P \text { for } \\
\text { trend }\end{array}$} \\
\hline & Q1 (lowest) & Q2 & Q3 & Q4 & Q5 (highest) & \\
\hline $\begin{array}{l}\text { Median } \mathrm{Mg} \\
\text { concentration (mmol/L) }\end{array}$ & 0.82 & 0.87 & 0.91 & 0.94 & 0.99 & - \\
\hline Participants (n) & 200 & 215 & 190 & 168 & 189 & - \\
\hline DM (\%) & 23.5 & 10.7 & 10.0 & 8.3 & 6.3 & - \\
\hline Model 1* & 1.00 (reference) & 0.38 (0.22 to 0.66$)$ & 0.34 (0.19 to 0.61$)$ & 0.29 (0.15 to 0.55$)$ & $0.20(0.10$ to 0.40$)$ & $<0.001$ \\
\hline Model 2* & 1.00 (reference) & $0.40(0.23$ to 0.70$)$ & 0.32 (0.18 to 0.59$)$ & 0.26 (0.13 to 0.50$)$ & 0.21 (0.11 to 0.42$)$ & $<0.001$ \\
\hline$P$ values & - & 0.001 & $<0.001$ & $<0.001$ & $<0.001$ & - \\
\hline Model 3* & 1.00 (reference) & $0.40(0.23$ to 0.70$)$ & $0.33(0.18$ to 0.60$)$ & 0.27 (0.14 to 0.52 ) & 0.22 (0.11 to 0.44$)$ & $<0.001$ \\
\hline$P$ values & - & 0.001 & $<0.001$ & $<0.001$ & $<0.001$ & - \\
\hline
\end{tabular}

Data are adjusted OR $(95 \% \mathrm{Cl})$, unless otherwise indicated.

*Model 1 was adjusted for age (continuous data) and gender (male, female); model 2 was adjusted for age (continuous data), Body Mass Index (continuous data), gender (male, female), educational level (high school or above, lower than high school), smoking status (yes, no), activity level (continuous data), alcohol drinking status (yes, no), hypertension (yes, no) and dyslipidemia (yes, no); model 3 was adjusted based on model 2 , with additional factor of estimated glomerular filtration rate (continuous data).

$\mathrm{DM}$, diabetes mellitus; Mg, magnesium; n, number; OA, osteoarthritis.

and cellular calcium homoeostasis. ${ }^{55} \mathrm{Mg}$ is an essential cofactor of the high-energy phosphate-bound enzymatic pathways involved in the modulation of glucose transport across cell membranes. ${ }^{57}$ It also plays a role in the mechanisms of cellular antioxidant defence. ${ }^{64}$ The oxidative stress, defined as a persistent imbalance between the excessive production of reactive oxygen species and/or defects in antioxidant defence, has been implicated in the pathogenesis of diabetic complications. ${ }^{57}$ Moreover, low serum $\mathrm{Mg}$ levels are strongly related to elevated serum concentrations of both tumour necrosis factor alpha and $\mathrm{C}$ reactive protein $(\mathrm{CRP}),{ }^{65}$ suggesting that $\mathrm{Mg}$ deficiency may contribute to the development of low-grade chronic inflammation syndrome and the development of glucose metabolic disorders through the former pathway. In addition, lower $\mathrm{Mg}$ concentration can enhance calcium-mediated vasoconstriction, blunt cardiac and smooth muscle relaxation, and thus contribute to BP elevation. ${ }^{55}$ However, the decreased serum calcium concentration in patients with radiographic knee OA may weaken the association between $\mathrm{Mg}$ and $\mathrm{HP}^{66}$

$\mathrm{MetS}^{2122}$ and $\mathrm{DM}^{42324}$ were reported to be the risk factors of $\mathrm{OA}$ progression. Moreover, serum $\mathrm{Mg}$ level has been proven to be significantly associated with CRP concentration, ${ }^{27}$ 67-69 and higher CRP might serve as a prediction factor for $\mathrm{OA}$ progression. ${ }^{70} 71$ Thus, OA

Table 4 Multivariable adjusted relations of serum Mg and HP in patients with OA ( $n=962)$

\begin{tabular}{|c|c|c|c|c|c|c|}
\hline & \multicolumn{5}{|c|}{ Quintiles of serum $\mathbf{M g}$} & \multirow{2}{*}{$\begin{array}{l}\mathrm{P} \text { for } \\
\text { trend }\end{array}$} \\
\hline & Q1 (lowest) & Q2 & Q3 & Q4 & Q5 (highest) & \\
\hline $\begin{array}{l}\text { Median Mg } \\
\text { concentration (mmol/L) }\end{array}$ & 0.82 & 0.87 & 0.91 & 0.94 & 0.99 & - \\
\hline Participants (n) & 200 & 215 & 190 & 168 & 189 & - \\
\hline HP (\%) & 40.0 & 33.5 & 37.4 & 42.3 & 40.2 & - \\
\hline Model $2^{\star}$ & 1.00 (reference) & 0.77 (0.50 to 1.19$)$ & 0.89 (0.57 to 1.39$)$ & $1.10(0.70$ to 1.74$)$ & 1.08 (0.69 to 1.68$)$ & 0.377 \\
\hline$P$ values & - & 0.245 & 0.608 & 0.686 & 0.744 & - \\
\hline Model $3^{*}$ & 1.00 (reference) & 0.77 (0.50 to 1.19$)$ & 0.88 (0.56 to 1.38$)$ & 1.09 (0.68 to 1.72$)$ & 1.05 (0.67 to 1.65$)$ & 0.434 \\
\hline$P$ values & - & 0.235 & 0.574 & 0.727 & 0.818 & - \\
\hline
\end{tabular}

Data are adjusted OR $(95 \% \mathrm{Cl})$, unless otherwise indicated.

*Model 1 was adjusted for age (continuous data) and gender (male, female); model 2 was adjusted for age (continuous data), Body Mass Index (continuous data), gender (male, female), educational level (high school or above, lower than high school), smoking status (yes, no), activity level (continuous data), alcohol drinking status (yes, no), diabetes (yes, no) and dyslipidemia (yes, no); model 3 was adjusted based on model 2, with additional factor of estimated glomerular filtration rate (continuous data).

$\mathrm{HP}$, hypertension; Mg, magnesium; $\mathrm{n}$, number; OA, osteoarthritis. 
Table 5 Multivariable adjusted relations of serum $\mathrm{Mg}$ and $\mathrm{HU}$ in patients with $\mathrm{OA}(\mathrm{n}=962)$

\begin{tabular}{|c|c|c|c|c|c|c|}
\hline & \multicolumn{5}{|c|}{ Quintiles of serum $\mathbf{M g}$} & \multirow{2}{*}{$\begin{array}{l}P \text { for } \\
\text { trend }\end{array}$} \\
\hline & Q1 (lowest) & Q2 & Q3 & Q4 & Q5 (highest) & \\
\hline $\begin{array}{l}\text { Median } \mathrm{Mg} \\
\text { concentration } \\
\text { (mmol/L) }\end{array}$ & 0.82 & 0.87 & 0.91 & 0.94 & 0.99 & - \\
\hline Participants (n) & 200 & 215 & 190 & 168 & 189 & - \\
\hline HU (\%) & 25.5 & 19.1 & 13.2 & 18.5 & 14.8 & - \\
\hline$P$ values & - & 0.157 & 0.002 & 0.144 & 0.010 & - \\
\hline Model $2^{*}$ & 1.00 (reference) & 0.73 (0.45 to 1.20$)$ & 0.38 (0.22 to 0.67$)$ & 0.59 (0.35 to 1.02$)$ & 0.50 (0.29 to 0.87$)$ & 0.006 \\
\hline$P$ values & - & 0.210 & 0.001 & 0.058 & 0.013 & - \\
\hline Model $3^{*}$ & 1.00 (reference) & 0.68 (0.41 to 1.14$)$ & 0.33 (0.19 to 0.59$)$ & $0.52(0.30$ to 0.91$)$ & 0.39 (0.22 to 0.70$)$ & $<0.001$ \\
\hline$P$ values & - & 0.142 & $<0.001$ & 0.022 & 0.001 & - \\
\hline
\end{tabular}

Data are adjusted OR $(95 \% \mathrm{Cl})$, unless otherwise indicated.

*Model 1 was adjusted for age (continuous data) and gender (male, female); model 2 was adjusted for age (continuous data), Body Mass Index (continuous data), gender (male, female), educational level (high school or above, lower than high school), smoking status (yes, no), activity level (continuous data), alcohol drinking status (yes, no), hypertension (yes, no), diabetes (yes, no) and dyslipidemia (yes, no); model 3 was adjusted based on model 2, with additional factor of estimated glomerular filtration rate (continuous data). $\mathrm{HU}$, hyperuricaemia; Mg, magnesium; n, number; OA, osteoarthritis.

progression may be delayed by elevating the serum $\mathrm{Mg}$ level through reducing the prevalence of MetS and DM and decreasing the level of CRP. Above all, the present study indicated that the elevation of serum $\mathrm{Mg}$ level has the potential to reduce the prevalence of MetS, DM and $\mathrm{HU}$ in patients with knee OA and may delay the progression of knee OA. However, the specific mechanism needs to be further explored.

The present study has several strengths. First, this is the first study examining the associations between serum $\mathrm{Mg}$ and the prevalence of MetS, DM, HP and HU in patients with radiographic knee OA. The results of this study will provide a new insight into the treatment of knee OA. Second, the multivariable logistical regression models were adjusted for a considerable number of potential confounding factors, which greatly improved the reliability of the results. Third, the kidney is the key organ in maintaining $\mathrm{Mg}$ homoeostasis. This study conducted a sensitivity analysis by adding eGFR into multivariable logistic regression models, which showed that the reverse associations remained significant.

Limitations of the present study should also be admitted. The cross-sectional design precludes causal correlations, so further prospective studies and intervention trials should be undertaken to establish a causal association between serum $\mathrm{Mg}$ with the prevalence of MetS, DM, HP and HU in patients with radiographic knee OA. Since no previous research investigated such associations in patients with knee OA, the value of this study should not be blotted out by the cross-sectional nature. Another limitation of this study lies in the relatively small sample size, and thus, extensive high-quality researches based on a larger sample are needed. Moreover, the dietary intake of $\mathrm{Mg}$ in relation to the prevalence of MetS, DM, HP and HU was not assessed in the present study. Last but not the least, it is important to highlight that $\mathrm{Mg}$ is an intracellular ion; therefore, the serum $\mathrm{Mg}$ concentration must be considered as a poor indicator of body $\mathrm{Mg}$ content ${ }^{72}$ even though it has been used in many studies. However, blood $\mathrm{Mg}$ level is the second best indicator of body status. ${ }^{73}$

\section{CONCLUSIONS}

The present study concluded that the serum Mg concentration was inversely associated with the prevalence of MetS, DM and HU in patients with radiographic knee OA.

\section{Author affiliations}

${ }^{1}$ Department of Orthopaedics, Xiangya Hospital, Central South University, Changsha, Hunan, China

${ }^{2}$ Health Management Center, Xiangya Hospital, Central South University, Changsha, Hunan, China

${ }^{3}$ International Medical Center, Xiangya Hospital, Central South University, Changsha, Hunan, China

Contributors All authors had full access to the data in the study and take responsibility for the integrity of the data and the accuracy of the data analysis. GL, YW and JW conceived the study. GL, YW and JW were responsible for conception and design of the study and drafted the manuscript. CZ, TY, HL, YC and DX contributed to data collection. JW contributed to preparation and data analysis. BX, ZL, JL and SJ contributed to study retrieval. GL and YW contributed to revision of the manuscript. All the authors contributed to the interpretation of the data and critically reviewed the manuscript for publication.

Funding This work was supported by the Innovation Foundation of the Central South University for Postgraduate (2018zzts045), the Postdoctoral Science Foundation of Central South University (182130), the National Natural Science Foundation of China (nos. 81201420, 81272034, 81472130, 81501923), the Provincial Science Foundation of Hunan (no. 14JJ3032), the Scientific Research Project of the Development and Reform Commission of Hunan Province ((2013)1199), the Scientific Research Project of Science and Technology Office of Hunan Province (2013SK2018) and the Doctoral Scientific Fund Project of the Ministry of Education of China (20120162110036).

Competing interests None declared.

Patient consent Obtained. 
Ethics approval The protocol has been reviewed and approved by the Ethics Committee of Xiangya Hospital, Central South University (reference no. 201312459), and the methods were developed in accordance with the approved guidelines.

Provenance and peer review Not commissioned; externally peer reviewed.

Data sharing statement The data sets during the current study are available from the corresponding author on reasonable request.

Open access This is an open access article distributed in accordance with the Creative Commons Attribution Non Commercial (CC BY-NC 4.0) license, which permits others to distribute, remix, adapt, build upon this work non-commercially, and license their derivative works on different terms, provided the original work is properly cited, appropriate credit is given, any changes made indicated, and the use is non-commercial. See: http://creativecommons.org/licenses/by-nc/4.0/.

\section{REFERENCES}

1. Zhuo Q, Yang W, Chen J, et al. Metabolic syndrome meets osteoarthritis. Nat Rev Rheumatol 2012;8:729-37.

2. Katz JD, Agrawal S, Velasquez M. Getting to the heart of the matter: osteoarthritis takes its place as part of the metabolic syndrome. Curr Opin Rheumatol 2010;22:512-9.

3. Berenbaum F. Diabetes-induced osteoarthritis: from a new paradigm to a new phenotype. Ann Rheum Dis 2011;70:1354-6.

4. King KB, Rosenthal AK. The adverse effects of diabetes on osteoarthritis: update on clinical evidence and molecular mechanisms. Osteoarthritis Cartilage 2015;23:841-50.

5. Kirkman MS. Osteoarthritis progression: is diabetes a culprit? Osteoarthritis Cartilage 2015;23:839-40.

6. Sellam J, Berenbaum F. Is osteoarthritis a metabolic disease? Joint Bone Spine 2013;80:568-73.

7. Puenpatom RA, Victor TW. Increased prevalence of metabolic syndrome in individuals with osteoarthritis: an analysis of NHANES III data. Postgrad Med 2009;121:9-20.

8. Shin D. Association between metabolic syndrome, radiographic knee osteoarthritis, and intensity of knee pain: results of a national survey. $J$ Clin Endocrinol Metab 2014;99:3177-83.

9. Calvet J, Orellana C, Larrosa M, et al. High prevalence of cardiovascular co-morbidities in patients with symptomatic knee or hand osteoarthritis. Scand J Rheumatol 2015:1-4.

10. Rahman MM, Kopec JA, Cibere J, et al. The relationship between osteoarthritis and cardiovascular disease in a population health survey: a cross-sectional study. BMJ Open 2013;3:e2624.

11. Inoue R, Ishibashi $Y$, Tsuda $E$, et al. Medical problems and risk factors of metabolic syndrome among radiographic knee osteoarthritis patients in the Japanese general population. J Orthop Sci 2011;16:704-9.

12. Hart DJ, Doyle DV, Spector TD. Association between metabolic factors and knee osteoarthritis in women: the Chingford Study. J Rheumatol 1995;22:1118-23.

13. Jungmann PM, Kraus MS, Alizai $\mathrm{H}$, et al. Association of metabolic risk factors with cartilage degradation assessed by $\mathrm{T} 2$ relaxation time at the knee: data from the osteoarthritis initiative. Arthritis Care Res 2013;65:1942-50.

14. Anagnostopoulos I, Zinzaras E, Alexiou I, et al. The prevalence of rheumatic diseases in central Greece: a population survey. BMC Musculoskelet Disord 2010;11:98.

15. Massengale M, Reichmann WM, Losina E, et al. The relationship between hand osteoarthritis and serum leptin concentration in participants of The Third National Health and Nutrition Examination Survey. Arthritis Res Ther 2012;14:R132.

16. Nieves-Plaza M, Castro-Santana LE, Font YM, et al. Association of hand or knee osteoarthritis with diabetes mellitus in a population of Hispanics from Puerto Rico. J Clin Rheumatol 2013;19:1-6.

17. Greiver M, Williamson T, Barber D, et al. Prevalence and epidemiology of diabetes in Canadian primary care practices: a report from the Canadian Primary Care Sentinel Surveillance Network. Can J Diabetes 2014;38:179-85.

18. Rahman MM, Cibere J, Anis AH, et al. Risk of Type 2 Diabetes among osteoarthritis patients in a prospective longitudinal study. Int $J$ Rheumatol 2014;2014:1-7.

19. Reid JL, Morton DJ, Wingard DL, et al. Obesity and other cardiovascular disease risk factors and their association with osteoarthritis in Southern California American Indians, 2002-2006. Ethn Dis 2010;20:416-22.

20. Birtwhistle R, Morkem R, Peat G, et al. Prevalence and management of osteoarthritis in primary care: an epidemiologic cohort study from the Canadian Primary Care Sentinel Surveillance Network. CMAJ Open 2015;3:E270-5.
21. Yoshimura N, Muraki S, Oka H, et al. Accumulation of metabolic risk factors such as overweight, hypertension, dyslipidaemia, and impaired glucose tolerance raises the risk of occurrence and progression of knee osteoarthritis: a 3-year follow-up of the ROAD study. Osteoarthritis Cartilage 2012;20:1217-26.

22. Monira Hussain S, Wang Y, Cicuttini FM, et al. Incidence of total knee and hip replacement for osteoarthritis in relation to the metabolic syndrome and its components: a prospective cohort study. Semin Arthritis Rheum 2014;43:429-36.

23. Schett G, Kleyer A, Perricone C, et al. Diabetes is an independent predictor for severe osteoarthritis: results from a longitudinal cohort study. Diabetes Care 2013;36:403-9.

24. Eymard F, Parsons $\mathrm{C}$, Edwards $\mathrm{MH}$, et al. Diabetes is a risk factor for knee osteoarthritis progression. Osteoarthritis Cartilage 2015;23:851-9.

25. Guerrero-Romero F, Rodríguez-Morán M. Low serum magnesium levels and metabolic syndrome. Acta Diabetol 2002;39:209-13.

26. Guerrero-Romero F, Rodríguez-Morán M. Hypomagnesemia, oxidative stress, inflammation, and metabolic syndrome. Diabetes Metab Res Rev 2006;22:471-6.

27. Evangelopoulos AA, Vallianou NG, Panagiotakos DB, et al. An inverse relationship between cumulating components of the metabolic syndrome and serum magnesium levels. Nutr Res 2008;28:659-63.

28. Hjelmesaeth J, Hofsø D, Aasheim ET, et al. Parathyroid hormone, but not vitamin $\mathrm{D}$, is associated with the metabolic syndrome in morbidly obese women and men: a cross-sectional study. Cardiovasc Diabetol 2009;8:7.

29. Lima ML, Cruz T, Rodrigues LE, et al. Serum and intracellular magnesium deficiency in patients with metabolic syndromeevidences for its relation to insulin resistance. Diabetes Res Clin Pract 2009;83:257-62.

30. Ma J, Folsom AR, Melnick SL, et al. Associations of serum and dietary magnesium with cardiovascular disease, hypertension, diabetes, insulin, and carotid arterial wall thickness: the ARIC study. Atherosclerosis Risk in Communities Study. J Clin Epidemiol 1995;48:927-40.

31. Kao WH, Folsom AR, Nieto FJ, et al. Serum and dietary magnesium and the risk for type 2 diabetes mellitus: the Atherosclerosis Risk in Communities Study. Arch Intern Med 1999;159:2151-9.

32. Wang JL, Shaw NS, Yeh HY, et al. Magnesium status and association with diabetes in the Taiwanese elderly. Asia Pac J Clin Nutr 2005;14:263-9.

33. Chambers EC, Heshka S, Gallagher D, et al. Serum magnesium and type-2 diabetes in African Americans and Hispanics: a New York cohort. J Am Coll Nutr 2006;25:509-13.

34. Simmons D, Joshi S, Shaw J. Hypomagnesaemia is associated with diabetes: not pre-diabetes, obesity or the metabolic syndrome. Diabetes Res Clin Pract 2010;87:261-6.

35. Sales CH, Pedrosa LF, Lima JG, et al. Influence of magnesium status and magnesium intake on the blood glucose control in patients with type 2 diabetes. Clin Nutr 2011;30:359-64.

36. Lecube A, Baena-Fustegueras JA, Fort JM, et al. Diabetes is the main factor accounting for hypomagnesemia in obese subjects. PLoS One 2012;7:e30599.

37. $\mathrm{Xu} \mathrm{J}, \mathrm{Xu} \mathrm{W}, \mathrm{Yao} \mathrm{H}$, et al. Associations of serum and urinary magnesium with the pre-diabetes, diabetes and diabetic complications in the Chinese Northeast population. PLoS One 2013;8:e56750.

38. Yang SJ, Hwang SY, Baik SH, et al. Serum magnesium level is associated with type 2 diabetes in women with a history of gestational diabetes mellitus: the Korea National Diabetes Program study. J Korean Med Sci 2014;29:84-9.

39. Singh RB, Rastogi V, Niaz MA, et al. Epidemiological study of magnesium status and risk of hypertension in a rural population of north India. Magnes Res 1996;9:173-81.

40. Peacock JM, Folsom AR, Arnett DK, et al. Relationship of serum and dietary magnesium to incident hypertension: the Atherosclerosis Risk in Communities (ARIC) Study. Ann Epidemiol 1999;9:159-65.

41. Guerrero-Romero F, Rodríguez-Morán M, Hernández-Ronquillo G, et al. Low serum magnesium levels and its association with high blood pressure in children. J Pediatr 2016;168:93-8.

42. Zeng C, Wang YL, Wei J, et al. Association between low serum magnesium concentration and hyperuricemia. Magnes Res 2015;28:56-63.

43. Zeng C, Wei J, Li H, et al. Relationship between serum magnesium concentration and radiographic knee osteoarthritis. J Rheumatol 2015;42:1231-6.

44. Wei J, Zeng C, Gong Q-yi, et al. Associations between dietary antioxidant intake and metabolic syndrome. PLoS One 2015;10:e130876. 
45. Xie DX, Xiong YL, Zeng C, et al. Association between low dietary zinc and hyperuricaemia in middle-aged and older males in China: a cross-sectional study. BMJ Open 2015;5:e8637.

46. Wei J, Zeng C, Gong QY, et al. The association between dietary selenium intake and diabetes: a cross-sectional study among middle-aged and older adults. Nutr J 2015;14:18.

47. Expert panel on metabolic syndrome of Chinese Diabetes Society: recommendations on metabolic syndrome of Chinese Diabetes Society (Chinese). Chin J Diabetes 2004;14:156-61.

48. Pang C, Jia L, Hou X, et al. The significance of screening for microvascular diseases in Chinese community-based subjects with various metabolic abnormalities. PLoS One 2014;9:e97928.

49. Zhou H, Guo ZR, Yu LG, et al. Evidence on the applicability of the ATPIII, IDF and CDS metabolic syndrome diagnostic criteria to identify CVD and T2DM in the Chinese population from a 6.3year cohort study in mid-eastern China. Diabetes Res Clin Pract 2010;90:319-25.

50. Levey AS, Stevens LA, Schmid $\mathrm{CH}$, et al. A new equation to estimate glomerular filtration rate. Ann Intern Med 2009;150:604-12.

51. Joosten MM, Gansevoort RT, Mukamal KJ, et al. Urinary magnesium excretion and risk of hypertension: the prevention of renal and vascular end-stage disease study. Hypertension 2013;61:1161-7.

52. Choi MK, Bae YJ. Association of magnesium intake with high blood pressure in Korean adults: Korea National Health and Nutrition Examination survey 2007-2009. PLoS One 2015;10:e130405.

53. R Development Core Team. R: a language and environment for statistical computing. Vienna, Austria: R Foundation for Statistical Computing, 2016.

54. Grundy SM, Cleeman JI, Daniels SR, et al. Diagnosis and management of the metabolic syndrome: an American Heart Association/National Heart, Lung, and Blood Institute Scientific Statement. Circulation 2005;112:2735-52.

55. Barbagallo M, Dominguez LJ, Galioto A, et al. Role of magnesium in insulin action, diabetes and cardio-metabolic syndrome X. Mol Aspects Med 2003;24(1-3):39-52.

56. Song Y, Ridker PM, Manson JE, et al. Magnesium intake, C-reactive protein, and the prevalence of metabolic syndrome in middle-aged and older U.S. women. Diabetes Care 2005;28:1438-44.

57. Guerrero-Romero F, Rodríguez-Morán M. Complementary therapies for diabetes: the case for chromium, magnesium, and antioxidants. Arch Med Res 2005;36:250-7.

58. Huerta MG, Roemmich JN, Kington ML, et al. Magnesium deficiency is associated with insulin resistance in obese children. Diabetes Care 2005;28:1175-81.

59. Djurhuus MS, Skøtt P, Hother-Nielson O, et al. Insulin increases renal magnesium excretion: a possible cause of magnesium depletion in hyperinsulinaemic states. Diabet Med 1995;12:664-9.
60. Paolisso G, Sgambato S, Passariello N, et al. Insulin induces opposite changes in plasma and erythrocyte magnesium concentrations in normal man. Diabetologia 1986;29:644-7.

61. Bonora E, Targher G, Zenere MB, et al. Relationship of uric acid concentration to cardiovascular risk factors in young men. Role of obesity and central fat distribution. The Verona Young Men Atherosclerosis Risk Factors Study. Int J Obes Relat Metab Disord 1996;20:975-80.

62. Lyngdoh T, Marques-Vidal P, Paccaud F, et al. Elevated serum uric acid is associated with high circulating inflammatory cytokines in the population-based Colaus study. PLOS One 2011;6:e19901.

63. Kirilmaz B, Asgun F, Alioglu E, et al. High inflammatory activity related to the number of metabolic syndrome components. $J$ Clin Hypertens 2010;12:136-44.

64. Salmonowicz B, Krzystek-Korpacka M, Noczyńska A. Trace elements, magnesium, and the efficacy of antioxidant systems in children with type 1 diabetes mellitus and in their siblings. Adv Clin Exp Med 2014;23:259-68.

65. Rodríguez-Morán M, Guerrero-Romero F. Elevated serum concentration of tumor necrosis factor-alpha is linked to low serum magnesium levels in the obesity-related inflammatory response. Magnes Res 2004;17:189-96.

66. Li H, Zeng C, Wei J, et al. Serum calcium concentration is inversely associated with radiographic knee osteoarthritis: a cross-sectional study. Medicine 2016;95:e2838.

67. Chacko SA, Song Y, Nathan L, et al. Relations of dietary magnesium intake to biomarkers of inflammation and endothelial dysfunction in an ethnically diverse cohort of postmenopausal women. Diabetes Care 2010;33:304-10

68. Bo S, Durazzo M, Guidi S, et al. Dietary magnesium and fiber intakes and inflammatory and metabolic indicators in middleaged subjects from a population-based cohort. Am J Clin Nutr 2006;84:1062-9.

69. Kim DJ, Xun P, Liu K, et al. Magnesium intake in relation to systemic inflammation, insulin resistance, and the incidence of diabetes. Diabetes Care 2010;33:2604-10.

70. Spector TD, Hart DJ, Nandra D, et al. Low-level increases in serum C-reactive protein are present in early osteoarthritis of the knee and predict progressive disease. Arthritis Rheum 1997;40:723-7.

71. Smith JW, Martins TB, Gopez E, et al. Significance of C-reactive protein in osteoarthritis and total knee arthroplasty outcomes. Ther Adv Musculoskelet Dis 2012:4:315-25.

72. Topf JM, Murray PT. Hypomagnesemia and hypermagnesemia. Rev Endocr Metab Disord 2003;4:195-206.

73. Sabatier M, Pont F, Arnaud MJ, et al. A compartmental model of magnesium metabolism in healthy men based on two stable isotope tracers. Am J Physiol Regul Integr Comp Physiol 2003;285:R656-63. 